Teologia i Moralność, volumen 16(2021), numer 1(29)

doi: 10.14746/TIM.2021.29.1.6

ORICD: 0000-0001-5685-7861

MONIKA LEWICKA

Uniwersytet Kazimierza Wielkiego w Bydgoszczy

Wydział Pedagogiki

\title{
Dziecko w sytuacji rozwodu rodziców. Implikacje pedagogiczne
}

\author{
To, co nam przynosi życie, \\ Może być zarówno końcem, \\ Jak i początkiem.
}

(A. Gide)

\section{Wprowadzenie}

Rodzina, w której przychodzi na świat dziecko, to środowisko, w którym istotną rolę odgrywają nie tylko jego członkowie, ale i relacje między nimi oraz przekaz wartości. Od jakości więzi w niej (nie)istniejących, socjalizacji, stylów wychowania, systemu wartości, ale przede wszystkim od zaufania, udzielonego wsparcia i miłości w znacznym stopniu zależy jakość funkcjonowania danej jednostki w życiu codziennym. To pierwsze i podstawowe środowisko dla dziecka jest naturalnym fundamentem, na którym buduje ono swoją tożsamość, poczucie wartości oraz system aksjologiczny. Zdarza się też, że środowisko rodzinne nie stanowi właściwego fundamentu dla rozwoju dziecka. Okazuje się „siłą" działającą destrukcyjnie, utrudniającą lub wręcz uniemożliwiającą realizację planów życiowych (Kliszek 2019, 9). Przestrzeń rodzinna, w której wzrasta dziecko, bywa też (ze względu na złożoność różnych zależności) pewnym konglomeratem budujących i destrukcyjnych oddziaływań tworzących fundament pod przyszłe, dorosłe życie.

Od początku XIX wieku wraz z przemianami ustrojowymi i towarzyszącymi im zmianami w świadomości społecznej, które między innymi odnosiły się do postrzegania funkcjonowania rodziny, jej roli i funkcji w życiu człowieka 
oraz jej trwałości, wzrasta liczba rozwodów. W przestrzeni społecznej stały się one obecnie powszechnym zjawiskiem. Sytuację taką mamy także w naszym kraju. Według danych Głównego Urzędu Statystycznego w 2019 roku zostało orzeczonych 65341 rozwodów, a począwszy od 1980 roku zauważalna jest tendencja rosnąca (Rozkrut 2020, 230-249). Rozwiązanie małżeństwa poprzez rozwód określają przepisy, które dopuszczają taką możliwość w sytuacji zupełnego i trwałego rozkładu pożycia (art. $56 \$ 1$ Kodeksu rodzinnego i opiekuńczego). Rozkład jest zupełny, gdy nie istnieje między małżonkami więź duchowa, fizyczna ani gospodarcza.

Rozwód i jego przyczyny należą do zjawisk wielowymiarowych i wieloaspektowych. Ze wspomnianych danych statystycznych Głównego Urzędu Statystycznego wynika, że do głównych przyczyn rozwodów należą: niezgodność charakterów (najczęściej wymieniana), niedochowanie wierności małżeńskiej, nadużywanie alkoholu, naganny stosunek do członków rodziny, trudności mieszkaniowe, nieporozumienia na tle finansowym, niedobór seksualny, dłuższa nieobecność, różnice światopoglądowe, religijne, powody medyczne, wiek zawarcia związku małżeńskiego ${ }^{1}$ (Rozkrut 2020, 230-249; Ubong 2018, 173-174). Często wskazywanymi powodami rozwiązania związku małżeńskiego są „niezgodność charakterów” lub „różnice charakterów niemożliwe do pogodzenia". Powód ten - ze względu na swoją wieloznaczność - z jednej strony traktowany jest jako swoisty pojemny „worek”, do którego wrzuca się wszystkie te przyczyny, które są nośnikiem trudności połączonych z dużą dozą skrępowania. Stanowi to niejako ,akt grzecznościowy” wobec byłego już partnera/partnerki. Z drugiej strony mogą się kryć za nim błahe nieporozumienia, które na drodze dialogu mogłyby zostać rozwiązane bez konieczności rozwodu. W takim wypadku chodzi o nadanie owym konfliktom rangi poważnego problemu, a w rzeczywistości przyczyna powodująca pragnienie rozstania może okazać się bardzo prozaiczna.

Wymienione przyczyny rozwodu warto uzupełnić o te, które związane są z laicyzacją życia społecznego i związaną z nią zmianą wzorców lansowanych przez kulturę masową oraz tolerancją prawodawstwa cywilnego większości krajów rozwiniętych wobec rozwodów (Kamińska-Berezowska 2001, 148; Hashemi, Homayuni 2017, 1). Można przypuszczać, że współczesne rodziny są w większym stopniu narażone na dezorganizację i rozpad niż te żyjące przed okresem wzmożonej industrializacji (Kaja 2013, 128). Kryzys rodziny, jaki obserwujemy na przestrzeni lat, napawa niepokojem. $Z$ drugiej zaś strony powinien prowadzić do refleksji na temat konsekwencji rozpadu rodziny dla dziecka i jego rozwoju (Popek 2016, 34). Warto dodać, że winien być impulsem do podjęcia konkretnych działań.

\footnotetext{
${ }^{1}$ Dane na dzień 31.12.2020.
} 
Przyczyny rozwodu wyjaśnia również teoria wymiany społecznej, której głównym założeniem jest teza, że jednostki wchodzące ze sobą w interakcję, usiłują maksymalizować zyski i minimalizować straty. Relacja jest kontynuowana do momentu, w którymi zyski przewyższają straty. Jest ona szczególnie przydatna $\mathrm{w}$ analizie zjawisk dotyczących rodziny, zarówno w aspekcie mechanizmów doboru małżeńskiego, jak i tych, które prowadzą do jego rozpadu (Blau 2006, 82-90).

\section{Rozwód jako sytuacja trudna}

W sytuacji pojawienia się nieustannych i długotrwałych konfliktów, braku porozumienia pomiędzy małżonkami, często również działań nieetycznych, zaczynają być stosowane mechanizmy zaradcze, które wobec niepowodzenia prowadzą do podjęcia przez jedną (lub obie) strony decyzji o rozwiązaniu związku małżeńskiego. Formalne rozwiązanie małżeństwa wiąże się z separacją lub rozwodem (Szukalski 2013, 116). Rozwód pojawia się w rodzinach o zróżnicowanym statusie społecznym, wykształceniu i stażu małżeńskim (Kaja 2013, 128). Można rozpatrywać go dwojako: biorąc pod uwagę jego procesualny charakter i fazowość zjawisk, jakie jemu towarzyszą. Zaburza cykl życia rodziny i równowagę w systemie rodzinnym (Józefik 2005, 169$-170)$.

Rozwód traktowany jest jako zdarzenie krytyczne ze względu na istotę zmian, jakie zachodzą w życiu osobistym, rodzinnym, społecznym i zawodowym małżonków, oraz oddziaływanie na osobowość ich dziecka (Piotrowska 2011, 188-189). Nadal ujmowany jest w kategoriach pejoratywnych, traktowany w kontekście dysfunkcji rodziny (Sokołowska 2013, 110). Niesie ze sobą konsekwencje w postaci utraty (przynajmniej chwilowej) poczucia bezpieczeństwa, oparcia i struktury życiowej, rozpatrywanej w perspektywie względnie stałej organizacji czasu i zadań (Błażek, Lewandowska 2017, 53).

Rozwód prowadzi do zmiany (Kowaluk-Romanek, Bednarz-Grzybek 2012, 77-78), jest właściwie serią przemian modyfikujących życie uczestniczących w nim osób (Beisert 2000, 123). Traktowany jest jako traumatyzujące zdarzenie dla dziecka, głównie ze względu na dwie sytuacje. Pierwsza dotyczy okresu przed rozwodem, który jest dla dziecka źródłem stresu i napięć. Zazwyczaj doświadcza ono sytuacji trudnej, związanej z konfliktem rodziców, brakiem pozytywnych stosunków pomiędzy nimi. Sytuacja druga ma miejsce już po rozwodzie, kiedy dziecko doświadcza wychowywania się w rodzinie niepełnej (bez biologicznego ojca lub matki; Dzierżanowski 2010, 256).

Barbara Kaja przywołuje za Judsonem Landisem siedem sytuacji trudnych, w których znajduje się dziecko przeżywające rozwód rodziców: „ko- 
nieczność przystosowania do zarysowującej się perspektywy rozwodu; konieczność przystosowania do faktu zaistnienia rozwodu; możliwość wykorzystania dziecka przez jedno lub oboje rodziców jako broni przeciw drugiemu rodzicowi; konieczność zmiany stosunków z rodzicami; nowy status dziecka rodziców rozwiedzionych; uświadomienie sobie przez dziecko implikacji niepowodzenia rodziców w małżeństwie; problem przystosowania się do ewentualnego następnego rozwodu" (Kaja 1992, 22).

Doświadczanie rozwodu rodziców jest również trudne ze względu na to, że często dziecko związane jest z obojgiem rodziców. Niejednokrotnie konieczność niejako opowiedzenia się po stronie jednego z nich może prowadzić do wystąpienia u dziecka poczucia winy, braku bezpieczeństwa, zranienia, złości. Atmosfera nieustannej kłótni pomiędzy rodzicami wywołuje u dziecka zaburzenia emocjonalne, stany napięcia emocjonalnego, lęki i zmniejsza odporność na stres (Cudak 2003, 103; Hashemi, Homayuni 2017, 2-3).

Rozwód to czas, w którym rodzina musi przepracować swego rodzaju żałobę. Powoduje ją to, co nie udało się partnerom, potrzebny jest więc czas na przeanalizowanie sytuacji. Jak każdą żałobę, rozwód trzeba przejść, ,przepracować”. W przeciwnym razie pozostaje złość i agresja, która bezpośrednio może rzutować na dobro dziecka (Namysłowska 2020, 132). Natomiast zaangażowani w rozwód małżonkowie mają do wykonania przede wszystkim dwa zadania. Pierwsze dotyczy sytuacji osobistej każdego z nich - „ułożenia” sobie od nowa życia, odnalezienia się w ,nowej” sytuacji porozwodowej. Drugie związane jest z ochroną dziecka przed uwikłaniem go w konflikt pomiędzy rodzicami oraz pomoc w wychowaniu wspólnego dziecka (Piotrowska 2011, 190). Warto również podkreślić, że osoby rozwodzące się najczęściej nie mają przestrzeni na ekspresję swoich uczuć, na otrzymanie wsparcia w sferze życia społecznego. Większość osób samotnie przechodzi przez ten okres (Józefik 2005, 170).

Możemy również wymienić dwukierunkowość następstwa rozwodu. $\mathrm{Z}$ jednej strony podkreśla się negatywne konsekwencje zaistniałej sytuacji. $Z$ drugiej zaś - biorąc pod uwagę teorie stresu, kryzysu, wydarzeń krytycznych i psychologii life-span - poszukuje się pozytywnych konsekwencji (Kowaluk-Romanek, Bednarz-Grzybek 2012, 79). W intencji rodziców rozwód ma stanowić zakończenie, rozwiązanie sytuacji trudnej w związku małżeńskim.

Mirosława Nowak-Dziemianowicz podejmuje refleksję nad skutkami negatywnego wartościowania rozpadu związku małżeńskiego, zaliczania go do patologii i dewiacji społecznej lub rodzinnej. Autorka dodaje, że takiej interpretacji zazwyczaj towarzyszą charakterystyczne określenia, takie jak: ,rodzina rozbita”, „rodzina porzucona”, „rozkład rodziny”. Stanowisko to, zdaniem autorki, skazuje ludzi (stygmatyzuje - M.L.), którzy doświadczyli rozwodu, na jeszcze większą krzywdę, porażkę czy poczucie winy. Nowak-Dziemiano- 
wicz przyjmuje rozumienie rozwodu w kontekście „zdarzenia krytycznego”, które jednak nie musi być ukierunkowane na rozpacz, destrukcję czy dezintegrację, ale może stać się szansą rozwoju osobistego, okazją do tego, aby dojrzeć emocjonalnie (Nowak-Dziemianowicz 2002, 233-235). Rozwód ujmowany jest również w kategoriach „trajektorii cierpienia” i jest - zdaniem autorki - „wydarzeniem niosącym ze sobą ból i cierpienie. Jego istotą jest odczucie bezładu, utraty kontroli nad własnym życiem, niemożność spełnienia dotychczasowych, organizujących własną biografię oczekiwań oraz towarzyszące tym zjawiskom cierpienie" (Nowak-Dziemianowicz 2002, 237). Monika Popek $(2016,34)$ stawia tezę, że skoro miłość jest prawem przysługującym każdemu człowiekowi, gwarantującym mu wzrost i rozwój, to pozbawienie go może być interpretowane w kategoriach przemocy.

Interpretując rozwód w koncepcji trajektorii cierpienia, człowiek go doświadczający musi niejako zdefiniować swoją sytuację życiową tak, aby nie został w tej trajektorii „uwięziony” lub ,zapętlony”. Można to zrobić albo przez próbę teoretycznego przepracowania załamania się systemu orientacji oraz trajektorii, poprzez odnalezienie przyczyn tego cierpienia, analizę wpływu cierpienia na obecne funkcjonowanie danej jednostki lub w sposób praktyczny, a więc podjęcia praktycznych działań mających na celu kontrolę trajektorii lub ucieczkę od niej. Możliwa jest też ,systematyczna organizacja życia z trajektorią oraz systematyczna eliminacja potencjału trajektoryjnego", co da się wykonać tylko w przypadku całkowitej reorganizacji sytuacji życiowej, a wpisana jest w to ,praca biograficzna nad własnym rozwojem osobowym" (Nowak-Dziemianowicz 2002, 247-248). Autorka traktuje systematyczną organizację życia z trajektorią jako sposób adaptacji jednostki do sytuacji rozwodu (Nowak-Dziemianowicz 2002, 255), zaś ucieczkę od niej jako sposób, który akcentuje „,nierozwiązywalność, niemożność poradzenia sobie z zamętem", jaki wywołuje rozwód w życiu jednostki (Nowak-Dziemianowicz $2002,259)$. W radzeniu sobie $\mathrm{z}$ doświadczeniem rozwodu istotną rolę odgrywają „znaczący inni” - „opiekunowie na trajektorii” - dzięki nim możliwe jest podjęcie trudu „renormalizacji pękniętej codzienności” (Nowak-Dziemianowicz 2002, 272).

\section{Rodzina w ujęciu systemowym}

Człowiek jest istotą społeczną, chce być w relacjach z innymi, obawia się samotności (Kliszek 2019, 9). Rodzina powszechnie uważana jest za podstawową jednostkę życia społecznego. Relacja pomiędzy matką a ojcem jest dla dziecka pierwszym i zarazem najważniejszym wzorem relacji interpersonalnych. Jakość i trwałość tych relacji stanowi istotny komponent trwałych, sta- 
bilnych schematów emocjonalnych i poznawczych (Müller-Siekierska, Wesołowska 2017, 37-38). Pojmowanie rodziny uzależnione jest oczywiście od przyjętej perspektywy. Rodzina jest przedmiotem wielu dyscyplin naukowych. W psychologii, socjologii i pedagogice (w zależności od kontekstu) ujmuje się ją jako instytucję, grupę społeczną, środowisko wychowawcze i system psychospołeczny (Kowaluk-Romanek, Bednarz-Grzybek 2012, 73). Rozpatruje się ją także w kontekście instytucjonalnym socjalizacyjnym (Kliszek 2019, 17-18) oraz jako grupę intymną, gdzie prawo interweniuje w wyjątkowych sytuacjach (Łączkowska 1999, 45).

Coraz częściej rodzinę traktuje się w kategorii systemu². Takie ujęcie pozwala na zrozumienie wzajemnych oddziaływań rodzice-dziecko, a także wielu struktur i układów w niej panujących (dziecko-dziecko, matka-ojciec - dop. M. L.; Kliszek 2019, 45). Każdy członek rodziny traktowany jest jako podsystem, zaś jego najbliższe otoczenie (rodzina) jako system. Całość nie może być rozpatrywana oddzielnie, bez uwzględnienia zależności i interakcji, jakie zachodzą pomiędzy poszczególnymi członkami systemu (rodziny). Systemowe ujęcie rodziny podkreśla złożoność procesów zachodzących w różnych sytuacjach jej codziennego życia (Kowaluk-Romanek, Bednarz-Grzybek 2012, 74). Niezależnie od przyczyny, każde zmiany w systemie dotyczące jego składu osobowego (na skutek śmierci, wyjazdu za granicę, separacji, rozwodu, samotnego rodzicielstwa) w sposób specyficzny oddziałują na dziecko, stwarzając niejednokrotnie trudności wychowawcze oraz zaburzając jego rozwój (Kowaluk-Romanek, Bednarz-Grzybek 2012, 77). Rodziny nie możemy nigdy postrzegać jako sumę właściwości poszczególnych członków (nie jest to proste działanie matematyczne), ale jako iloczyn wspólnych i indywidualnych procesów zachodzących w tej najmniejszej (ale zarazem najważniejszej) grupie społecznej.

Ujmowanie rodziny $\mathrm{w}$ kategoriach systemu pozwoliło na rozpatrywanie rozwodu z jej perspektywy. Istotę tego podejścia oddają następujące stwierdzenia:

1. „Rozwód powoduje zmianę w formule rodziny

2. Rozwód jak każdy kryzys stwarza ryzyko powstania następstw pozytywnych i negatywnych

3. Przyczyny zmian rozwojowych występujących u dzieci rozwiedzionych rodziców tkwią w konfliktowej relacji dorosłych i w sposobie jej rozwiązywania

4. Działania zaradcze uruchamiane przez dorosłych członków rodziny w odpowiedzi na kryzys rozwodu wpływają na działania zaradcze dzieci” (Beisert 2000, 122).

\footnotetext{
${ }^{2}$ Słowo system pochodzi z j. greckiego systema i oznacza złożoną rzecz (Kliszek 2019, s. 46).
} 
Rozpatrując rodzinę jako system, możemy założyć, że zachodzące w niej relacje wpływają na rozwój emocjonalny (i nie tylko - dop. M.L) dziecka. Badania wskazują, że rozwodzący się rodzice nie chronią dzieci przed udziałem w konfliktach, często próbują je niejako „przekupić”. Takie zachowanie prowadzi do zaburzeń emocjonalnych, braku poczucia bezpieczeństwa i odrzucenia emocjonalnego (Beczkiewicz 2015, 339).

Rodzina oddziałuje na swoich członków przez całe życie, choć wpływ ten jest zdecydowanie większy w okresie dzieciństwa i młodości. Poczucie bezpieczeństwa, jakie daje dziecku atmosfera życzliwości, sprawia, że stanie się ono jednostką silną, dobrze radzącą sobie w życiu. Prawidłowa więź rodzinna jest podstawą bezpieczeństwa. Natomiast jej brak prowadzić może do zaniku odporności psychicznej, niedojrzałości emocjonalnej. Dziecko rozwija się dzięki rodzicom i relacji z nimi (Kliszek 2019, 23-24). Wypełniają oni przypisane im przez daną kulturę funkcje i zadania. Zdaniem Tomasza Szlendaka, rodzinę konstytuują następujące funkcje: prokreacyjna, wychowawczo-socjalizacyjna, opiekuńcza, emocjonalno-seksualna, ekonomiczna/gospodarcza, stratyfikacyjna/alokacyjna i integracyjno-kontrolna (Szlendak 2000, 314). Wszystkie są niezwykle istotne dla jej prawidłowego funkcjonowania.

\section{Sytuacja dziecka doświadczającego rozwodu rodziców}

Po ogólnym zarysowaniu trudności i problemów, jakie niesie ze sobą rozwód dla wszystkich członków rodziny, więcej uwagi poświęcić należy sytuacji dziecka. Bardzo silnie i intensywnie przeżywa ono otaczający go świat, osoby i rzeczy, które się w nim znajdują.

Doświadczając rozwodu rodziców, odbiera go głównie jako zagrożenie poczucia bezpieczeństwa, ma także obniżone poczucie własnej wartości (Piotrowska 2011, 193). Nie ma wątpliwości, że rozwód jest jednym z najbardziej niekorzystnych wydarzeń w jego życiu (Auersperg, Vlasak, Ponocny, Barth $2019,107)$. Dziecko często staje się po nim członkiem tzw. ,rodziny patchworkowej” (Kliszek 2019, 88) definiowanej jako „swoista układanka”. Sytuacja taka dotyczy rodzin, w których miał miejsce rozwód i nastąpiło ponowne założenie rodziny przez jednego lub obojga rodziców. W takiej sytuacji najczęściej pojawia się drugi rodzic utrzymujący kontakt z dzieckiem, dziecko/dzieci „nowego" partnera/partnerki i członkowie ich rodzin (Kliszek 2019, 88). Podobnie jak dorośli, dziecko przechodzi przez sytuację kryzysu rozwodowego stadialnie. Zdaniem Wallersteina i Blakeslee (2015), można wskazać trzy następujące po sobie stadia: uświadomienie sobie przez dziecko realności zerwania małżeństwa przez rodziców, wyłączenie się z konfliktu pomiędzy rodzicami i zaakceptowanie straty (Błażek, Lewandowska-Walter 2017, 156-158). 
Uczucia towarzyszące dziecku doświadczającemu rozwodu rodziców są różne w zależności od fazy emocjonalnej, w jakiej się ono znajduje, oraz pozostałych czynników, tj. płci, wieku, stopnia przywiązania dziecka do rodziców, jego indywidualnych cech, relacji rodziców z dzieckiem w sytuacji przedrozwodowej, percepcji sytuacji rozwodowej i porozwodowej (Piotrowska 2011, 193; Kuźniewska 2019, 78-81). Wyróżnić możemy następujące uczucia (Hart 2006, 171-172):

1. Lęk i niepokój. Rozwód prowadzi do zmian w codziennym funkcjonowaniu dziecka, wywołuje lęk przed nieznanym, narusza podstawy bezpieczeństwa. Dziecko w sytuacji rozwodu rodziców może doświadczać wielu klasycznych oznak lęku i niepokoju (nerwowości, bezsenności, różnego rodzaju dolegliwości bólowych). Dziecko może być zaniepokojone z powodu utrudnionego kontaktu $\mathrm{z}$ nieobecnym rodzicem.

2. Poczucie opuszczenia i odrzucenia przez odchodzącego rodzica. Poczucie to może być silniejsze w sytuacji, w której rodzic zwiąże się z kolejnym partnerem/partnerką, która/który ma dziecko/dzieci.

3. Samotność i smutek związany z zaburzeniem regularnego rytmu dnia (posiłki, wspólne spędzanie czasu wolnego). Atmosfera kłótni również niejako znika, ulega wyciszeniu. Pozostaje pustka. Często dzieci w tej fazie mają nadzieję, że rodzice będą ponownie razem. Utwierdzenie się w przekonaniu, że jest to niemożliwe, prowadzi do jeszcze większego smutku i może być początkiem depresji.

4. Frustracja i złość pojawia się niedługo po wystąpieniu smutku. Dziecko oczekuje, że jego życie wróci do „,normy” z czasu przed wystąpieniem rozwodu. Gdy okazuje się, że jest to niemożliwe, uczucia dziecka są blokowane lub niedostrzegane. W takiej sytuacji niejednokrotnie wywołuje to u niego frustrację, która z kolei prowadzi do wystąpienia złości.

5. Odrzucenie i uraza, zwłaszcza w stosunku do rodziców. Dziecko dystansuje się do nich, tworząc emocjonalny dystans między sobą a nimi. Dzieje się tak na skutek lęku dziecka przed kolejnym zranieniem. Jest też pewnego rodzaju karą dla rodzica/rodziców za to, co się stało.

Moc odziaływania oraz skutki rozwodu dla dziecka zależą od wielu czynników. Jako główny wskazywane jest przywiązanie do rodziców i postrzeganie sytuacji rodzinnej przed rozwodem. Jeśli dziecko było świadkiem nieustannych konfliktów, przemocy, uzależnienia jednego z rodziców, często rozwód traktuje jako ulgę, sytuację, która zakończy ten trudny czas. Natomiast jeśli dziecko postrzega swoją rodzinę jako szczęśliwą, w niej czuje się bezpiecznie, informacja o rozwodzie rodziców jest dla niego traumą (Dzierżanowski 2010, 259). Radzenie sobie z rozwodem rodziców zależy oczywiście od postawy rodziców względem dziecka. Niezwykle trudne są dla niego komunikaty rodzica/rodziców oczekujące bezwzględnej lojalności wobec jednego z nich 
(najczęściej wobec tego, z którym dziecko mieszka) przyjmujące postać hasła „albo jesteś ze mną, albo przeciwko mnie”. Sytuacja, w której dziecko ma dokonać tak trudnego wyboru, dodatkowo implikuje w nim poczucie winy i niskiej wartości.

Radzenie sobie z rozwodem rodziców zależy też od wieku. Niewątpliwe sytuacja jest trudna dla każdego dziecka, jednak małe dzieci są bardziej podatne na negatywne czynniki rozpadu rodziny. Znajdują się pod większym wpływem emocjonalnym swoich rodziców. W sytuacji, w której atmosfera $\mathrm{w}$ domu jest napięta, zdecydowanie utrudnione jest utworzenie prawidłowego kodu emocjonalnego u dziecka (przywiązania - dop. M. L.; Dzierżanowski 2000, 60). Należy jednak podkreślić, że nie ma takiego wieku rozwojowego, w którym rozwód i towarzyszące mu sytuacje i emocje nie stwarzałyby zagrożeń dla prawidłowego rozwoju psychicznego (emocjonalnego i społecznego - dop. M.L.) dziecka (Dzierżanowski 2010, 260-261).

Sposób doświadczania rozwodu rodziców jest kwestią indywidualną. $\mathrm{U}$ jednego dziecka proces radzenia sobie $\mathrm{z}$ tą trudną sytuacją trwa do około dwóch lat, u drugiego może trwać o wiele dłużej (nawet do 10 lat po rozstaniu rodziców). Są dzieci, które szybciej adaptują się do tej sytuacji, są też takie, którym rozwód zapada głęboko w pamięć i utrudnia prawidłowe funkcjonowanie w życiu dorosłym (Piotrowska 2011, 196). Przepracowanie kryzysu związanego z rozwodem rodziców zajmuje dzieciom około 5-7 więcej czasu niż rozwodzącym się małżonkom (Sokołowska 2013, 120).

Na sposób radzenia sobie z rozwodem rodziców duży wpływ ma również to, co dzieje się z dzieckiem później. Inna jest sytuacja dziecka wychowywanego przez samotnego rodzica, inna, gdy żyje w rodzinie zrekonstruowanej lub patchworkowej (dop. - M.L.). Inne jest doświadczenie dziecka, nad którym rodzice sprawują naprzemienną opiekę, od tego, które nie ma kontaktu ze swoim biologicznym rodzicem (dop. - M.L.) oraz tego, którego rodzice po rozwodzie nadal mieszkają razem (Stanowska 2012, 149-150). Efektywność radzenia sobie z rozstaniem rodziców wzrasta, gdy wyższa jest efektywność radzenia sobie rodziców z rozwodem. Wydaje się słuszna teza, że dzieci oczekują czegoś innego od matki i od ojca. Dla dziecka obraz efektywnej matki, która radzi sobie z rozwodem w sposób konstruktywny, jest niezwykłą pomocą i ułatwia mu radzenie sobie $\mathrm{z}$ tą trudną sytuacją. Natomiast obraz efektywnego i aktywnego w życiu dziecka ojca, który wypełnia obowiązki rodzicielskie, pomaga dziecku zaadaptować się do zachodzących w rodzinie zmian. Jest dla dziecka podejściem wzmacniającym. Czynnikiem, który prowadzi do (efektywnego) radzenia sobie z kryzysem, jest również brak konfliktu między rodzicami (Beisert 2000, 277-279). Irena Namysłowska (2020, 136-140) w swojej książce używa zwrotu „Rodzice, czyli architekci rodziny”, który wydaje się niezwykle trafny również w odniesieniu do rozwodu. Rodzice (po- 
mimo rozwodu - nadal nimi pozostają) mogą bowiem niejako „projektować” sytuację okołorozwodową i porozwodową, w taki sposób, by wspomagać dziecko w radzeniu sobie $\mathrm{z}$ tym trudnym dla niego doświadczeniem. Część z nich jednak funkcjonuje „bez projektu”, co zakończyć się może pominięciem fundamentalnych kwestii. Do takich z pewnością należy dobro dziecka, które zostaje pominięte, gdyż dorośli bardziej koncentrują się na rozwiązywaniu własnych spraw i radzeniu sobie ze swoimi emocjami.

Pozytywnej adaptacji dziecka do rozwodu rodziców sprzyjają trzy grupy czynników (Błażek, Lewandowska-Walter 2017, 140-141):

1. o charakterze indywidualnym (płeć, szczególne uzdolnienia, wysoki poziom rozumienia sytuacji społecznych, cechy temperamentalne i osobowościowe dziecka);

2. o charakterze rodzinnym (prawidłowa komunikacja w rodzinie, więzi uczuciowe, poczucie akceptacji, relacje $\mathrm{w}$ rodzinach zrekonstruowanych, zdolność rodziców do współpracy rodzicielskiej po rozwodzie, dbałość rodziców i opiekunów o wytworzenie u dziecka poczucia własnej wartości i świadomości własnych uzdolnień, prawidłowe relacje z rodzeństwem);

3. o charakterze społecznym (sieć wsparcia, wartościowe środowisko rówieśnicze, okazana we właściwym momencie pomoc specjalistyczna).

\section{Konsekwencje rozwodu. (Nowy) wymiar dzieciństwa}

Paul Bohannan wyróżnia sześć typów rozwodu; ze względu na problematykę zawartą w niniejszym artykule na szczególną uwagę zasługuje ten rozwód rodzicielski, który rozumiany jest jako uregulowanie praw i obowiązków względem dzieci. Autor zauważa, że rozwód nie powoduje rozwiązania relacji z dzieckiem, jego skutkiem natomiast jest zmiana dotychczasowego „obrazu” rodziny (zmiana miejsca zamieszkania jednego rodzica, zmiana typu opieki nad dzieckiem; Kowaluk-Romanek, Bednarz-Grzybek 2012, 77-78).

Dziecko w sytuacji rozwodu rodziców często przyjmuje rolę opiekuna swojego rodzica (zjawisko tzw. parentyfikacji). Może to się przejawiać w pocieszaniu, troszczeniu się o rodzica, sprawianiu mu przyjemności, ulgi, zmniejszaniu swoich potrzeb, emocji lub wręcz zaprzeczaniu, aby nie obciążać jeszcze bardziej (w rozumieniu dziecka) rodzica, który doświadczył rozwodu. Taka postawa utrudnia prawidłowy i harmonijny rozwój (Popek 2016, 41). Najstarsze dziecko wielokrotnie staje się dla rodzica partnerem w wychowywaniu młodszego rodzeństwa, przyjmując rolę „,bohatera” czy „odpowiedzialnego". Zauważalny jest tutaj brak granic w relacjach z rodzicem (najczęściej matką), albowiem to rodzic, a nie rodzeństwo, odpowiedzialny jest za wycho- 
wanie młodszego dziecka (Stankowska 2012, 158). Skutkiem takiej postawy jest wielokrotnie poczucie chronicznego zmęczenia i problemy z koncentracją uwagi. Konsekwencją takiej sytuacji jest też zwykle przedwczesna separacja i odcięcie emocjonalne (Błażek, Lewandowska 2017, 135). Takie dziecko przedwcześnie staje się dorosłe.

Rozwód rodziców wywołuje u dziecka trwały uraz, którego nie można wyleczyć, można jedynie złagodzić jego objawy. Dziecko doświadczające rozwodu rodziców zazwyczaj ma obniżoną samoocenę, brakuje mu wiary we własne umiejętności, czuje winę i bezradność. Wydarzenia, w których uczestniczy, utrudniają mu stworzenie prawidłowego wzorca rodziny, jego dorosłe życie często jest trudne i bardziej skomplikowane niż w przypadku dzieci wychowywanych w rodzinach pełnych (Müller-Siekierska, Wesołowska 2017, 38-41). Warto w tym miejscu przedstawić tezę, że współcześnie mamy do czynienia z powszechnością rozwodów, które są traktowane jako sposób na rozwiązanie trudności w relacji. Owa powszechność stała się (pod wpływem ogólnych przekonań) przyczyną uznawania rozwodu za niemal normatywny sposób rozwiązywania kryzysu w rodzinie. Teza ta jest jednak niemożliwa do utrzymania w momencie zetknięcia z rzeczywistością. Osoby doświadczające rozwodu, zwłaszcza w okresie przechodzenia przez tę sytuację, a także często później, gdy zmagają się z licznymi trudnościami, nie traktują go jako zdarzenia pozytywnego. Jest on sytuacją trudną, kryzysową, ma liczne konsekwencje (Błażek, Lewandowska 2017, 17-18).

Sposoby radzenia sobie z konfliktem, jakim jest rozwód rodziców, próbuje wyjaśnić teoria emocjonalnego bezpieczeństwa (Emotional Security Theory - EST, autorstwa Cummings i Davies 2001). Pozwala ona zrozumieć, jaki wpływ na adaptację dziecka do niekorzystnej pod względem wychowawczym atmosfery w rodzinie, mają takie czynniki, jak: organizacja i regulacja emocjonalnych odpowiedzi na sytuację konfliktu rodziców. W skład teorii wchodzą trzy główne wzorce: reaktywność emocjonalna, regulacja w sytuacji ekspozycji na konflikt oraz wewnętrzne reprezentacje. Pierwszy wzorzec charakteryzują negatywne reakcje emocjonalne na konflikt rodziców (tj. intensywny i przedłużający się lęk, czujność oraz reakcje stresowe). Wzorzec drugi odnosi się do behawioralnego udziału dziecka w konflikcie. W takiej sytuacji może ono przyjąć różne postawy: od czynnej (rola mediatora, pośrednika, powiernika), opowiedzenia się po stronie jednego z rodziców, po stronę bierną (unikanie ekspozycji na konflikt rodziców). Trzeci wzorzec uwarunkowany jest rodzajem konsekwencji konfliktu. W przypadku konfliktu konstruktywnego reprezentacje dziecka odnosić się będą do oczekiwanych pozytywnych konsekwencji (dziecko odczuwa ulgę). Natomiast w przypadku konfliktu destruktywnego aktywowane są u dziecka systemy regulacyjne, których celem jest zmiana sytuacji w rodzinie (Błażek, Lewandowska 2017, 79-82). 


\section{Jak wspierać dziecko podczas rozstania rodziców? Implikacje pedago- giczne}

Truizmem wydaje się stwierdzenie, że niewłaściwe jest uwikłanie przez rodziców swoich dzieci w sytuację okołorozwodową. Dorośli podejmują decyzję, ale jej konsekwencje w znacznym stopniu odczuwane są przez dzieci, które nie mają na nią wpływu. Podczas rozwodu wielu rodziców pochłoniętych jest swoimi emocjami, sprawami, nie poświęca należytej uwagi i pomocy swojemu dziecku, które często jest świadkiem przemocy fizycznej lub psychicznej. W takiej sytuacji nie doświadcza ono wystarczającej opieki, nie zostaje zaspokojona jego potrzeba bezpieczeństwa. Wówczas bardzo często dochodzi do zaniedbania dziecka, krzywdzenia go i przemocy wobec niego. Szczególnie szkodliwa jest deprywacja emocjonalna; niezaspokojenie dziecięcej potrzeby przywiązania, co prowadzić może do tego, że dziecko stanie się lękliwe, wycofane, skłonne do izolacji. Rozwód rodziców jest dla niego sytuacją nową, porównywalną do straty bliskiej osoby, wobec czego powinno ono przeżyć i opłakać stratę. Rodzice mogą i powinni pomóc dziecku w tak trudnej sytuacji. Powinni być aktywnymi odbiorcami jego przeżyć emocjonalnych.

Krzywdzenie zaczyna się w sytuacji, w której potrzeby rodziców w sytuacji okołorozwodowej stają się nadrzędne wobec potrzeby zapewnienia stałości i bezpieczeństwa dziecka. Istotnym celem pracy z jego rodzicami jest podanie jasnych wskazówek, dotyczących tego, kiedy granica ta zostaje przekroczona (Mitręga 2017, 23-24).

Dla dziecka i jego prawidłowego rozwoju ważna jest więź z obojgiem rodziców. Rozwód traktowany jest więc jako rozwiązanie „osobistej relacji łączącej małżonków", nie jest zaś rozstaniem rodzica z dzieckiem. Rodzaj relacji pomiędzy rozwiedzionymi partnerami determinuje w istotnym stopniu funkcjonowanie dziecka (Beisert, Liberska, Matuszewska 2001, 175-177). Rodzice powinni tak długo, jak jest to konieczne, brać aktywny udział w wychowywaniu go. Życie codzienne i funkcjonowanie w „nowej” porozwodowej sytuacji może być łatwiejsze dla niego dzięki postawom rodziców. Powinni oni przygotować dziecko na tę sytuację, przedstawić jak najwięcej związanych z tym szczegółów (oczywiście adekwatnie do wieku dziecka), jak będzie wyglądać ich funkcjonowanie po rozstaniu rodziców. Warto wspomnieć, że działania zaradcze uruchamiane przez dorosłych w odpowiedzi na kryzys rozwodu wpływają na działania zaradcze dzieci.

Wiele trudności, których doświadcza dziecko, wynika z nieprawidłowej komunikacji pomiędzy rodzicami. Aby uniknąc sądowych sporów o dziecko, intensyfikujących i tak już trudną sytuację, w której się ono znalazło, warto skorzystać z oferty ośrodków mediacyjnych i uzyskać kompromis. Ponadto wszelkie trudne rozmowy, często nacechowane silnymi emocjami, dorośli po- 
winni prowadzić bez obecności dziecka. Istotne jest również, aby po rozwodzie starać się nie mówić źle o drugim rodzicu. Należy pamiętać, że zazwyczaj dziecko jest przywiązane do obojga rodziców, kocha ich. Ważne jest również, aby nie czynić z dziecka sojusznika, szpiega czy posłańca, osoby opowiadającej się po stronie matki lub ojca. Takie postępowanie może mieć negatywny wpływ na jego późniejsze losy. Wspólne wychowanie, świat wartości obojga rodziców jest niezwykle ważny, aby uniknąć chaosu w życiu dziecka. Prawidłowa komunikacja pomiędzy byłymi partnerami oznacza również permanentne ustalanie i konsultowanie decyzji dotyczących codziennego życia dziecka. Tylko poprzez wzajemną komunikację i współpracę pomiędzy rodzicami można minimalizować negatywne konsekwencje rozwodu dla dziecka (Piotrowska 2018, 78-79). Obraz siebie nastolatków jest zdecydowanie lepszy (bez względu na płeć), gdy style rodzicielstwa obojga rodziców charakteryzuje opiekuńczość, ale nie nadmierna kontrola (optymalność; Dunlop, Burns, Bermingham 2001, 117-134). Ważne jest również zadbanie o to, aby dziecko było po prostu dzieckiem.

Trudna sytuacja, w jakiej znajduje się dziecko doświadczające rozwodu rodziców, implikuje potrzebę podjęcia kompleksowych działań i badań nad jego sytuacją, aby w sposób świadomy i zgodny ze współczesną wiedzą pedagogiczną, psychologiczną i prawną w sposób należyty zabezpieczyć jego dzieciństwo i podstawowe potrzeby, które w sytuacji rozwodu ulegają deprywacji (Turczyk 2019, 203). Niejedno dziecko stojące w obliczu rozwodu rodziców poza wsparciem najbliższej rodziny powinno otrzymać pomoc zinstytucjonalizowaną, w pierwszej kolejności ze środowiska szkolnego (pedagoga, psychologa, wychowawcy) oraz specjalistów pracujących z rodziną w kryzysie (Piotrowska 2011, 197).

\section{Zamiast zakończenia}

Mimo że dla większości Polaków rodzina nadal jest najwyższą wartością, rokrocznie rośnie liczba rozwodów. Rozwód jest dla osób go doświadczających sytuacją trudną, czasami wręcz traumatyczną, zawsze jednak niosącą zapowiedź zmiany. Zaburza on funkcjonowanie rodziny i w znacznym stopniu determinuje zachowanie dziecka. Podjęcie decyzji o rozwodzie zazwyczaj łączy się z dylematami natury moralnej, społecznej (obyczajowej) i religijnej. $\mathrm{Z}$ założenia małżeństwo traktowane jest jako związek stały (nierozerwalny), dlatego zakończenie go często rozpatrywane jest w kategorii ,porażki życiowej”. Jest też zakończeniem czegoś, co miało przynosić poczucie satysfakcji. Sytuacji rozwodowej często towarzyszą wyrzuty sumienia związane z tym, że dziecko traci dom, a więc miejsce, które miało być z założenia „oazą”, bezpieczną bazą, w której doświadcza miłości i wsparcia. 
Mimo przedstawienia wielu negatywnych konsekwencji rozwodu, mających przede wszystkim wpływ na dziecko i jego rozwój, należy podkreślić, że czasami podjęcie decyzji o nim jest słuszne. Jest tak w przypadku rodzin dotkniętych uzależnieniem rodzica/rodziców, przemocą fizyczną lub/i psychiczną, brakiem poszanowania godności poszczególnych członków rodziny (Kardasz, Dutka 2019, 260).

\title{
A LCHILD IN A SITUATION OF DIVORCE OF PARENTS. PEDAGOGICAL IMPLICATIONS
}

\begin{abstract}
SUMMARY
The article discusses the issue of divorce and its consequences for the functioning of the child. The most frequently mentioned reasons for divorce and selected theories than can be used in the article's issues are indicated. The issue of divorce as a difficult situation has also been addressed, 'critical events', 'trajectories od suffering'. The child is shown in a situation of a divorce crisis, characterizing the stages of divorce that the experiencing child goes through. The emotions accompanying the child in the face of parents' divorce were also presented. Another issue raised in the article was how the child copes with the parents' divorce. Factors conductive to the positive adaptation of the child to divorce have been identified. The article also presents the pedagogical implications of how to support the child when parents break up.
\end{abstract}

Keywords: pedagogy, family, marriage, divorce, child, parenting, values, father, mother, motherhood, fatherhood

Słowa kluczowe: pedagogika, rodzina, rozwód, dziecko, rodzicielstwo, wartości, ojciec, matka, macierzyństwo, ojcostwo

\section{BIBLIOGRAFIA}

Auersperg, Felicitas, et al. 2019. Long-term effects of parental divorce on mental health - A meta-analysis. Journal of Psychiatric Research, 107-115.

Beczkiewicz, Maria. 2015. Moja przyszła rodzina w wypowiedziach dorostych dzieci rozwiedzionych rodziców. W: Rodzina jako wartość: wzory - modele - redefinicje, red. Wojciech Muszyński, 337-347. Torun: Wydawnictwo Adam Marszałek.

Beisert, Maria i Hanna Liberska i Mirosława Matuszewska. 2001. Od konfliktu do rozwodu. W: Matżeństwo. Męskość-kobiecość, miłość, konflikt, red. Hanna Liberska i Mirosława Matuszewska, 171-188. Poznań: Wydawnictwo Fundacji Humaniora.

Beisert, Maria. 2000. Rozwód. Proces radzenia sobie z kryzysem. Poznań: Wydawnictwo Fundacji Humaniora. 
Blau, Peter M. 2006. Wymiana społeczna, tłum. Dariusz Niklas. W: Współczesne teorie socjologiczne, Aleksandra Jasińska-Kania, Lech M. Nijakowski, Jerzy Szacki, Marek Ziółkowski (wybór i oprac.), T. 1, 82-90. Warszawa.

Błażek, Magdalena i Aleksandra Lewandowska-Walter. 2017. Rozwód jako proces. Perspektywa dorostych i dzieci. Warszawa: Wydawca Difin.

Cudak, Henry. 2003. Funkcjonowanie dzieci z rodzin rozwiedzionych. Toruń: Wydawnictwo Adam Marszałek.

D'Onofrio, Brian and Robert Emery. 2019. Parental divorce or separation and children's mental health. World Psychiatry. DOI: 10.1002/wps.20590

Dunlop, Rosemary and Alisa Burns and Suzanne Bermingham. 2001. Parent-Child Relations and Adolescent Self-Image Followind Divirce: A 10 Year Study. Journal of Youth and Adolescent, 30. DOI:10.1023/A:1010389923248

Dzierżanowski, Jerzy. 2000. Konflikty matżeńskie jako problem duszpasterski w świetle dokumentacji Sadu Biskupiego w Opolu (1980-1989). Opole: Uniwersytet Opolski.

Dzierżanowski, Jerzy. 2010. Psychospołeczna sytuacja dziecka w małżeństwach rozwodzących się. W: Rodzina w nurcie wspótczesnych przemian, red. Dariusz Krok i Paweł Landwójtowicz, Studia Interdyscyplinarne, 255-278. Opole: Uniwersytet Opolski.

Hart, Archibald. D. 2006. Rozwód. Jak ratować dzieci, [tłum.] Magdalena Ciszewska, Poznań: Wydawnictwo w Drodze.

Hashemi, Ladan and Halleh Homayuni, 2017. Emotional Divorce: Child's Well-Being. Journal of Divorce \& Remarriage. DOI:10.1080/10502556.2016.1160483

Józefik, Barbara. 2005. Problematyka rozwodu i rodzin zrekonstruowanych. Implikacje terapeutyczne. Państwo i Społeczeństwo, V (3).

Kaja, Barbara. 1992. Rozwód w rodzinie a osobowość dziecka. Bydgoszcz: Wyższa Szkoła Pedagogiczna.

Kamińska-Berezowska, Sławomira. 2001. Konflikt małżeński zakończony rozwodem w badaniach empirycznych: trudności i nowe perspektywy badawcze. W: Eseje socjologiczne, red. Władysław Jacher, 146-162. Katowice: Wydawnictwo Uniwersytetu Śląskiego.

Kliszek, Ewa. 2019. Rodzina wobec zagrożeń. Rodzina wobec szans. Socjopsychopedagogika rodziny. Studium rodziny petnej. Warszawa: Wydawnictwo Difin.

Kowaluk-Romanek, Marzena i Renata Bednarz-Grzybek. 2012. Dziecko w matni rozwodu rodziców. Roczniki Pedagogiczne, 4(40), 73-92.

Kuźniewska, Zofia. 2019. Wpływ rozwodu rodziców na psychikę dziecka. Influence of divorce on a child's psyche. Cywilizacja i Polityka, 17, 17, 76-89.

Łączkowska, Małgorzata. 1999. Wybrane zagadnienia z socjologii rodziny. W: Studium rodziny, red. Tomasz Rzepecki, 143-157, Poznań: Oficyna Współczesna.

Mitręga, Anna. 2017. Psychologiczne aspekty krzywdzenia dzieci w procesie rozstawania się $i$ rozwodu rodziców. W: Dzieci i młodzież w XXI wieku - ujęcie społeczne, red. Monika Maciąg, Kamil Maciąg, 22-30, Lublin: Wydawnictwo Naukowe Tygiel.

Matżeństwo. Rodzina. Rozwód, red. Kaja, Barbara. 2013. Bydgoszcz: Wydawnictwo Uniwersytetu Kazimierza Wielkiego.

Müller-Siekierska, Diana i Dorota Wesołowska. 2017. Doświadczanie trudności w budowaniu bliskich relacji interpersonalnych przez młodych dorosłych z rodzin rozwiedzionych. Roczniki Pedagogiczne, 9 (45), 4, 37-55. DOI: 10.18290/rped.2017.9.4-3

Namysłowska, Irena. 2020. Od rodziny nie można uciec. Rozmawiają C. Gawryś, K. Jabłońska. Warszawa: Wydawnictwo „Więź”.

Nowak-Dziemianowicz, Mirosława. 2002. Doświadczenia rodzinne w narracjach. Interpretacje sensów i znaczeń. Wrocław: Wydawnictwo Naukowe Dolnośląskiej Szkoły Wyższej Edukacji TWP we Wrocławiu.

Piotrowska, Maja. 2018. Komunikacja w rodzinie po doświadczeniu rozwodu. O zaletach płynacych $z$ dobrej i zdrowej komunikacji w rodzinach porozwodowych. W: Komunikacja a zmiana spo- 
łeczna, red. Jolanta Kędzior, Beata Krawiec, Małgorzata Biedroń, Anna Mitręga, 71-81. Wrocław: Instytut Pedagogiki Uniwersytetu Wrocławskiego. DOI: doi:10.34616/22.19.001

Piotrowska, Maja. 2011. Jak pomóc dziecku w obliczu rozwodu rodziców? Poradnictwo i mediacje dla rozwodzacych się rodziców. Wrocław: Prace Naukowe Uniwersytetu Ekonomicznego we Wrocławiu.

Popek, Monika. 2016. Rozwód jako forma przemocy wobec dziecka. Roczniki Teologiczne, LXIII, 3, 33-46. DOI: 10.18290/rt.2016.63.3-3

Sokołowska, Edyta. 2013. Dorosłe Dzieci Rozwiedzionych Rodziców - Przegląd teorii i badań. Ogrody Nauk i Sztuk, 3, 109-122.

Stankowska, Magdalena. 2012. Dlugoterminowe konsekwencje rozwodu. Problemy dorostych dzieci z rodzin rozwiedzionych. W: Wielość spojrzeń na malżeństwo i rodzinę, red. Anna Kwak i Mariola Bieńko, 175-185. Warszawa: Wydawnictwo UW.

Szlendak, Tomasz. 2000. Socjologia rodziny. Ewolucja. Historia. Zróżnicowanie. Warszawa: Wydawnictwo Naukowe PWN.

Szukalski, Piotr. 2013. Matżeństwo. Początek i koniec. Łódź: Wydawnictwo Uniwersytetu Łódzkiego.

Turczyk, Małgorzata. 2019. Ochrona dziecka w sytuacji rozstania rodziców - konceptualizacja przedmiotu badań. Rocznik Pedagogiczny 42, 197-204, DOI: 10.2478/rp-2019-0013

\section{Pozycje internetowe:}

Rocznik demograficzny, red. Dominik Rozkrut. 2020. Warszawa. Dostęp: 02.01.2021. https://stat. gov.pl.

Kodeks rodzinny $i$ opiekuńczy. Dostęp: 02.01.2021. http://isap.sejm.gov.pl/isap.nsf/DocDetails. xsp?id=wdu19640090059.

Monika Lewicka - dr, adiunkt badawczo-dydaktyczny w Katedrze Badań nad Edukacją Estetyczną, Wydział Pedagogiki, Uniwersytet Kazimierza Wielkiego w Bydgoszczy. Zainteresowania naukowe: problematyka rodziny, rodzicielstwa, dziecka i wartości. 